\title{
Use of Microscopy in the Study of Self-Hardening Al-Alloy for Automotive Application
}

Eva Tillová, Mária Chalupová, Lenka Kuchariková, Denisa Závodská, Juraj Belan, Alan Vaško

Faculty of Mechanical Engineering, University of Žilina, Univerzitná 8215/1, 01026 Žilina, Slovak Republic. E-mail: eva.tillova@fstroj.uniza.sk

Self-hardening secondary Al-Zn-Si-Mg alloys represent an innovative class of light Al-Si alloys. The most important and relevant feature of the self-hardening alloys is related to their good performance, without the need of any heat treatment. Mechanical properties depend upon the morphologies, type and distribution of the phases. It is therefore important to study the intermetallic phases occurring in the secondary Al-alloys, where they found more than in the primary-Al alloys. Study of intermetallic phases in the alloy was performed on an optical microscope using classical etching technique (by $0.5 \%$ HF) to invocation black-white contrast as well as unconventional methods for invocation colour contrast (etching by Weck-Al) to the observed surface of the sample. The colour metallography results were correlated with the information obtained by standard etching. The microstructures of the samples were analysed by scanning electron microscopy after standard etching and deep etching (with $\mathrm{HCl}$ ) too. After deep etching we are able to see the 3D morphology of eutectic Si particles and intermetallic phases.

Keywords: aluminium cast alloy, microstructure, intermetallic phases, morphology.

\section{Acknowledgement}

The authors acknowledge the financial support of the project VEGA No1/0533/15.

\section{References}

[1] PETER, I., ROSSO, M. (2015). Light Alloys - From Traditional to Innovative Technologies. Chapter 1. New Trends in Alloy Development, Characterization and Application. prof. Zaki Ahmad (Ed.), InTech.

[2] TILlOVÁ, E., CHALUPOVÁ, M. (2009). Structural analysis (Štruktúrna analýza), Edis Žilina (in Slovak).

[3] PEZDA, J. (2012). Heat Treatment of AlZn10Si7MgCu Alloy and its Effect on Change of Mechanical Properties. In: Archiwes of Foundry Engineering, Vol. 12 (2), pp. 135-138.

[4] PEZDA, J. (2013). Effect of T6 Treatment Parameters of AlZn10Si7MgCu Alloy on Change of its Hardness and Impact Strength. In: Archiwes of Foundry Engineering, Vol. 13 (1), pp. 143-146.

[5] ROSSO, M., PETER, I., CASTELlA, C., MOLINA, R. (2015). Optimization of Composition for Self-hardening AlZn10Si8Mg Alloys. In.: Materials Today: Proceedings. Vol. 2 (10), pp. 4949-4956.

[6] TILlOVÁ, E., ĎURINÍKOVÁ, E., CHALUPOVÁ, M. (2011). Structural analysis of secondary AlZn10Si8Mg cast alloy. In: Acta Metallurgica Slovaca, Vol. 17 (1), pp. 4-10.

[7] TIllovÁ, E., CHAluPOVÁ, M., HURTAlOVÁ, L., BELAN, J. (2015). Impact Properties of Self-Hardening Aluminium Alloy (AlZn10Si8Mg) at Elevated Temperatures. In.: Manufacturing Technology, Vol. 15 (4), pp. 720-727.

[8] www.alurheinfelden.com

[9] KRAL, M. V. (2005). A crystallographic identification of intermetallic phases in Al-Si alloys. In.: Materials Letters, Vol. 59 (18), pp. 2271- 2276.

[10] SAMUEL, E., SAMUEL, A. M., DOTY, H. V., VALTIERRA, S., SAMUEL, F. H. (2014). Intermetallic phases in Al-Si based cast alloys: new perspective. In.: International Journal of Cast Metals Research, Vol. 27 (2), pp. 107-114.

[11] TAYLOR, J. A. (2004). The effect of iron in Al-Si casting alloys. In.: 35th Australian Foundry Institute National Conference, pp. 148-157, Adelaide, South Australia.

[12] SEIFEDDINE, S. (2007). The influence of Fe on the microstructure and mechanical properties of cast Al-Si alloys. In. Literature review - Vilmer project. Jönköping University, Sweden.

[13] KRAL, M. V., MCINTYRE, H. R., SMILLIE, M. J. (2004). Identification of intermetallic phases in a eutectic AlSi casting alloy using electron backscatter diffraction pattern analysis. In.: Scripta Materialia, Vol. 51 (3), pp. 215 219.

[14] BOLIBRUCHOVÁ, D., ŽIHALOVÁ, M. (2013). Possibilities of iron elimination in aluminium alloys by vanadium. In: Manufacturing Technology, Vol. 13 (3), pp. 289-296. 